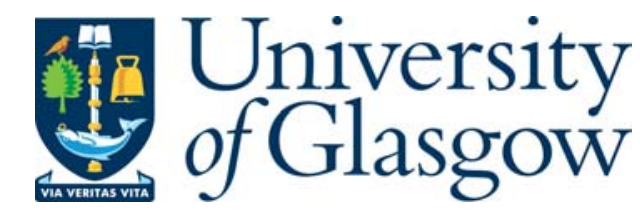

Fletcher, M. (2007) The problem of multiple criminal prosecutions: building an effective EU response. Yearbook of European Law.

http://eprints.gla.ac.uk/3811/

Deposited on: 8 November 2007 
The problem of multiple criminal prosecutions: building an effective EU response

\section{Maria Fletcher*}

The much anticipated Green Paper on conflicts of jurisdiction in criminal matters and the ne bis in idem principle was published by the Commission in January $2006 .{ }^{1}$ It forms the centre-piece of an on-going consultation by the Commission into the best possible way forward for the European Union in dealing with the problem of multiple prosecutions being pursued in different national jurisdictions on the basis of the same facts and the related principle of ne bis in idem. This short contribution explores the background to and justifications for a common EU response to these issues and outlines the possible responses as submitted by the Commission. It seeks to place these on going discussions within the context of a developing ECJ jurisprudence on the principle of ne bis in idem as enshrined in the Convention implementing the Schengen Agreement (CISA) and within the context of some of the key debates that resonate the field of EU criminal law cooperation - including human rights and the conception of an 'area of freedom, security and justice.' While few would deny the virtue of having 'one offence, one prosecution' in an Area of Freedom Security and Justice the question of how best to secure this depends ultimately upon how one

\footnotetext{
${ }^{*}$ Lecturer in European Law, University of Glasgow. Robin Lööf (doctoral candidate, European University Institute) read and commented upon an earlier draft of this work and made contributions towards its improvement, for which I am very grateful. The views expressed, and any errors, are mine. Additionally, I wish to gratefully acknowledge the Caledonian Research Foundation and Royal Society of Edinburgh for funding a period of study leave during which much of this article was written. ${ }^{1}$ Green Paper on Conflicts of Jurisdiction and the Principle of ne bis in idem in Criminal Proceedings COM(2005) 696, Brussels 23.12.2005. See also the Annex to the Green Paper SEC(2005) 1767, Brussels, 23.12.2005.
} 
envisages the European criminal judicial space and the role of the EU in creating it, (although, of course, the limits of existing legal competences and institutional dynamics must be factored into this important 'vision' discourse at the point of practical policy-making.) Member States authorities and other relevant stakeholders have expressed their concerns about the true extent of the problem of conflicts of criminal jurisdiction in practice and also the extent to which the Green Paper proposals might interfere with national procedures relating to investigation and prosecution. Such was the level of concern expressed in response to the Green Paper that the Hague Programme December 2006 deadline for the publication of a draft piece of legislation was missed and further impact assessment work is being undertaken by an organisation granted a tender by the Commission. It seems that more empirical evidence and perhaps conceptual argument is required before deciding upon how best to approach the issues of multiple prosecutions and ne bis in idem at the EU level.

\section{Background}

According to international criminal law, the choice of forum in which to bring a prosecution in criminal cases determines both the substantive and procedural law to be applied. The issue of where to prosecute therefore affects the interests of all parties involved in the criminal process - defendants, victims, witnesses, prosecutors, police, judges. At present there is no set of common rules at the international level, (UN, Council of Europe or the European Union) to determine which state has jurisdiction 
over a crime. ${ }^{2}$ The absence of such rules increases the likelihood of the initiation of parallel prosecutions for the same facts in different Member States. Indeed it is not difficult to imagine a situation - especially given the increase in trans-national crime and migratory flows - where more than one state has an interest in the prosecution of the same individual. However, multiple prosecutions are highly objectionable for several reasons; they are clearly detrimental to the individuals affected, they can cause problems in the international relations between States and they undermine the fundamental principle of ne bis in idem, which in its broad and general sense upholds that no-one should be prosecuted more than once for the same offence.

The ne bis in idem rule offers an important principle of judicial protection for the individual in the context of a fair trial. ${ }^{3}$ It is an established individual right in international human rights legal instruments ${ }^{4}$, it is enshrined in the domestic legal systems in most states and it is included in Council of Europe Conventions dealing with judicial cooperation in criminal matters as a ground for refusal to cooperate. ${ }^{5}$ Additionally, the principle seeks to safeguard the legitimacy and integrity of the legal system and of the state by safeguarding decisions which intend to definitively end

\footnotetext{
${ }^{2}$ Rather each Member State recognises some of the multiplicity of jurisdictional principles recognised by international law - the territoriality principle, the universality principle, the active and passive personality principles, the effects doctrine, the protective principle and the representational principle. All Member States agree on the territoriality principle - crimes committed wholly or partly within their territory fall within their jurisdiction - but there is no formal hierarchy of jurisdictional claims. See G.Conway 'Ne Bis in Idem in International Law' (2003) 3 International Criminal Law Review 217-244 at 225.

${ }^{3} \mathrm{~A}$ common rationale of the ne bis in idem principles in all its various forms is to protect individuals against possible abuses by the State of its ius puniendi.

${ }^{4}$ See for example Article 14(7) of the UN International Covenant on Civil and Political Rights, 19 December 1966 and Article 4 of the Seventh Protocol of the European Convention on Human Rights ${ }^{5}$ In this context the principle only applies between states if they have ratified the Convention and on the basis of a specific request. For instance Articles 7-9 of the Convention of the Council of Europe on Extradition of 13 December 1957 provide for ne bis in idem as a mandatory and optional ground for refusal to extradite. See also Articles 53-57 of the 1970 Convention of the Council of Europe on the International Validity of Criminal Judgments and Articles 35-37 of the 1972 Convention on the Transfer of Proceeding in Criminal Matters and Article 18(1)(e) of the 1990 Convention on Laundering, Search and Seizure and Confiscation of the Proceeds of Crime.
} 
criminal proceedings. On this understanding it plays an important role in upholding the principles of legal certainty and res judicata (finality) of criminal decisions. ${ }^{6}$

However, it was not until the adoption of the Convention implementing the Schengen agreement (CISA) in $1990^{7}$ that a common transnational ne bis in idem principle as an individual right erga omnes was established for the first time. ${ }^{8}$ Contrary to the traditional approach of treating the principle as a rule of domestic criminal justice ${ }^{9}$, the CISA extended the operation of the principle to an international level such that it applies in relations between EU Member States. Following the integration of CISA into the EU third pillar acquis by the Treaty of Amsterdam (in force May 1999) there have been calls for EU legislation to strengthen and clarify the ne bis in idem principle in the new context of developing the EU as a single 'area of freedom, security and justice. ${ }^{10}$ A Greek proposal for a Framework Decision on ne bis in idem in $2003^{11}$ was ultimately not seriously pursued due to concerns about its scope. The Commission in its 2005 Green Paper has relaunched discussions around a possible

\footnotetext{
${ }^{6}$ See for instance M.Friedland, Double Jeopardy (1969) (OUP), P.McDermott, Res Judicata and Double Jeopardy (1999) (Butterworths). On the relationship between the principle of finality and the protection of the individual against the ius puniendi of the State see the Law Commission's Report Double Jeopardy and Prosecution Appeals (March 2001) available at www.lawcom.gov.uk at 37-38

${ }^{7}$ Articles 54-58, The Convention implementing the Schengen Agreement of 14 June 1985 between the governments of the States of the Benelux Economic Union, the Federal Republic of Germany and the French Republic on the gradual abolition of checks at their common borders. Signed on 19 June 1990 at Schengen, Luxembourg. The CISA ne bis in idem principle is currently binding throughout the Schengen Area, the EU Member States that acceded in 2004 and 2007, in Iceland and Norway and in the UK; an extension to Ireland should follow soon. The text of 54 CISA reads as follows: "A person whose trial has been finally disposed of in one Contracting Party may not be prosecuted in another Contracting Party for the same acts provided that, if a penalty has been imposed, it has been enforced, is actually in the process of being enforced or can no longer be enforced under the laws of the sentencing Contracting Party.”

${ }^{8}$ J.A.E.Vervaele, 'The transnational ne bis in idem principle in the EU: Mutual recognition and equivalent protection of human rights’ Utrecht Law Review 1(2) December 2005 100-118 at 107. Also see M.Wasmeier and N.Thwaites, 'The Development of Ne Bis in Idem into a Transnational Fundamental Right in EU Law: Comments on Recent Developments’ E.L.Rev. (2006) 31(4) 565-578.

${ }^{9}$ Such as that enshrined in the European Convention for the protection of Human Rights and Fundamental Freedoms (ECHR). See Article 4 of Protocol 7 of 22 November 1984.

${ }^{10}$ Vienna Action Plan of the Council and the Commission on the implementation of the area of freedom, security and justice at point 49(e). OJ [1999] C19/1. See also the Commission Mutual Recognition Programme of measures to implement the principle of mutual recognition of decisions in criminal matters. OJ [2001] C12/1.

${ }^{11}$ OJ [2003] C100/4.
} 
legislative instrument dealing with ne bis in idem by linking the principle directly to the issue of positive conflicts of criminal jurisdiction. Meanwhile, the ECJ has been offering some much needed clarity on the role and scope of the CISA ne bis in idem principle in response to questions of interpretation referred to it by national courts. ${ }^{12}$ For the sake of completion, the ne bis in idem principle also appears in the EU acquis in the EU Charter of Fundamental Rights ${ }^{13}$ and in various framework decisions establishing the mutual recognition of national criminal law decisions as a ground for refusal to recognise/enforce foreign decisions in EU mutual recognition instruments. ${ }^{14}$

Turning to how the issue of criminal jurisdiction has been dealt with in EU law, certain third pillar legislative instruments contain provisions that require Member States to assert their jurisdiction over specific offences on the basis of certain jurisdictional principles. ${ }^{15}$ As a rule, the territoriality principle appears as a mandatory ground for establishing jurisdiction, while other listed grounds for asserting jurisdiction (such as the nationality principle and the passive personality principle) are

\footnotetext{
12 Pursuant to Article 35 EU. See Joined Cases C-187/01 and C-385/01 Hüseyn Gözütok and Klaus Brügge, [2003] ECR I-1345, Case C-469/03 Filomeno Mario Miraglia, [2005] ECR I-2009, Case C436/04 Leopold Henri Van Esbroeck [2006] ECR I-2333, Case C-467/04 Gasparini judgement of 28 September 2006 (nyr), Case C-150/05 Van Straaten judgment of 28 September 2006 (nyr), Case C288/05 Kretzinger judgement of 18 July 2007 (nyr) and Case C-367/05 Kraijenbrink judgement of 18 July 2007 (nyr). Case C-297/07 Klaus Bourquain is pending before the ECJ. It concerns the issue of enforcement of criminal penalties. Case C-272/05 Bouwens was removed from the Court's Register by the President by an Order of 7 June 2006 following an indication by the referring Belgian court that a preliminary reference was no longer necessary in light of the judgment made in Van Esbroeck. This caselaw is discussed further below.
}

\footnotetext{
${ }^{13}$ Article 50 reads 'No one shall be liable to be tried or punished again in the criminal proceedings for an offence for which he or she has already been finally acquitted or convicted within the Union in accordance with the law.' In terms of scope, the principle enshrined in Article 50 appears to apply both within and between criminal jurisdiction in the EU. However, its terminology is more akin to the ECHR definition of the principle than that enshrined in 54 CISA. For a comparative analysis of the principle of ne bis in idem as interpreted in the EU and ECHR contexts and a normative explanation for the differences in approach see R. Lööf, '54 CISA and the principles of ne bis in idem' European Journal of Crime, Criminal Law and Criminal Justice (Forthcoming November 2007)

${ }^{14}$ Although the provisions vary greatly, for instance it is not always a mandatory ground for refusal.

${ }^{15}$ For instance see Framework Decisions on attacks against information systems (OJ [2005] L69/67,), combating the sexual exploitation of children and child pornography (OJ [2004] L13/44), combating terrorism (OJ [2002] L164/3). For a full list see the Annex to the Green Paper at 9.
} 
non-mandatory or conditional. These provisions however appear to address more directly the concept of negative conflicts (where no Member State has, or is willing to assert jurisdiction) rather than the concept of positive conflicts.

Of more relevance to the latter concept is the approach taken in some third pillar legislative measures of obliging Member States (or relevant national authorities of Member States) to cooperate with a view to centralising prosecution in a single Member State where more than one Member State has jurisdiction and can validly prosecute. ${ }^{16}$ One step further, is the approach adopted in the Framework Decision on Combating Terrorism, which says that Member States "may have recourse to any body or mechanism established within the European Union in order to facilitate cooperation between their judicial authorities and the coordination of their action.”17 A list of substantive criteria to be taken into account in any coordination efforts is also included. The inclusion of a cooperation obligation in legislative instruments certainly assists in tackling the problem of positive conflicts of jurisdiction. However, in practice, this approach depends upon national authorities being aware of other jurisdictions having a valid claim to prosecute. Moreover, this approach is necessarily sector specific, applying only in relation to the particular criminal activity dealt with by the EU legislative instrument.

Cooperation in respect of a broader spectrum of crimes has been encouraged by enabling national prosecution authorities to ask for assistance from the EU judicial

\footnotetext{
${ }^{16}$ For example see Article 7(3) of the Framework Decision on Euro-counterfeiting OJ [2000] L140/1,. Note that a comprehensive list of EU measures that deal with the issue of jurisdiction are provided in the Commission Green Paper.

${ }^{17}$ Article 9(2) Framework Decision on Combating Terrorism.
} 
cooperation body, Eurojust, in deciding upon the appropriate forum for prosecution. ${ }^{18}$

Articles 6(a) and 7(a) of the Decision establishing Eurojust empower this body to

facilitate in the settlement of disputes on positive and negative jurisdiction conflicts.

Some success has been recorded here but Eurojust itself acknowledges that its

facilitative capacity in this regard is not being fully exploited by national authorities. ${ }^{19}$

In the combined absence of any duty on national authorities to refer a case to Eurojust

and any authority for Eurojust to issue binding decisions, parallel prosecutions within

the EU may still persist. ${ }^{20}$

For the sake of completeness it is worth noting that the 1972 Council of Europe

Convention on Transfer of Proceedings provided for the possibility of one State to

renounce its claim to jurisdiction over an offence and agree that another jurisdiction

will bring a prosecution. ${ }^{21}$ The procedures are however highly complex and more than

\footnotetext{
${ }^{18}$ According to Article 4 of the Eurojust Decision it is competent to act in relation to the same types of crime and offences for which Europol is competent to act (in accordance with art. 2 of the Europol Convention of 26 July 1995). This now constitutes a broad category of crimes including, illegal trading and harm to the environment, crimes against property or public goods and crimes against life, limb, or personal freedom. In addition to the 'Europol crimes' Eurojust can exercise its powers in respect of computer crime, fraud and corruption and any offence affecting the EC's financial interests, money laundering, environmental crime, participation in a criminal organisation and 'any other offences committed together with the types of crime and offence previously mentioned'. Moreover, at the request of a competent authority of a Member State, and in accordance with its objectives, Eurojust may assist in investigations and prosecutions relating to 'any other offence.' See Council Decision 2002/187/JHA of 28 February 2002 setting up Eurojust with a view to reinforcing the fight against serious crime. OJ [2002] L63/1. Also see its “Guidelines for Deciding "Which Jurisdiction Should Prosecute?"' included in the Annex of the Eurojust Annual Report 2005, available via http://www.eurojust.europa.eu/ (accessed 30 /9/07)

${ }^{19}$ See Eurojust Annual Report 2005 available via http://www.eurojust.europa.eu/

${ }^{20}$ It has also been acknowledged that the variable status of national Eurojust members (whose powers are determined by national rather than EU law) may, in practice, impact upon the determination of an appropriate jurisdiction for prosecution. Finally, it is acknowledged in the Green Paper that Eurojust's powers apply in respect of certain offences (albeit a long list which includes at least those crimes for which Europol is competent) and therefore it could not suggest a solution to every conflict of jurisdiction that arises. Of course, an 'EU solution' to positive conflicts of jurisdiction relating to nonharmonised offences may be vigorously resisted by Member States for important national policy reasons. After all, it is arguable that a single criminal area only exists in respect of those crimes that have been positively harmonised by the EU.

${ }^{21}$ This amounts to an application of the 'representation' principle of jurisdiction.
} 
30 years after its elaboration, it has been signed by 17 Member States but it has only entered into force in 11 Member States.

So, from this brief overview, it becomes clear that the positive attribution of jurisdiction and the application of the trans-national principle of ne bis in idem are indeed linked. In the absence of any common rules to determine an appropriate jurisdiction for prosecution, the CISA principle of ne bis in idem works in a somewhat arbitrary way to determine jurisdiction by simply pre-empting it elsewhere once a final decision barring further prosecution has been taken in one State. The Commission states that 'by giving preference to whichever jurisdiction can first take a final decision, its effects amount to a "first come first served" principle.,22 Consequently it has been argued that currently the State in which a suspect is prosecuted is either determined by various forms of forum shopping - either on the part of the prosecution authorities or on the part of the individual suspect - or by chance according to the State of apprehension. ${ }^{23}$ Parallel prosecutions are therefore currently tolerated, at least until one Member State delivers a final decision, at which point the ne bis in idem rule applies to shield the accused from subsequent prosecution for the same offence in another Member State. At least from a practical perspective, the adoption of a common framework or mechanism to enable the allocation of a competent jurisdiction would reduce the instances of recourse to the CISA principle of ne bis in idem which must be a good thing. It would also open up the possibility to rethink the scope of the principle itself, in particular the conditions and exceptions

\footnotetext{
${ }^{22}$ See Commission Green Paper at 3. See also the 'Freiburg Proposal on concurrent jurisdictions and the prohibition of multiple prosecutions in the European Union.' November 2003, Max Planck Institute, Freiburg at 12.

${ }^{23}$ The Freiburg proposal, ibid.
} 
currently attached thereto. ${ }^{24}$ In the context of the EU as an Area of Freedom, Security

and Justice a mechanism for a choice of jurisdiction could enable the EU to secure a more effective application of the principle of mutual recognition, which lies at the heart of judicial cooperation in criminal matters in general and the CISA ne bis in idem principle in particular. ${ }^{25}$

$\underline{\text { Justifying an EU approach }}$

In light of the above, it might indeed be argued that a more effective solution to the problem of multiple prosecutions is both desirable and necessary at the EU level. Certainly there is a clear legal basis for the EU to adopt legislation in this regard. Article 31(1)(d) EU calls for EU action “preventing conflicts of jurisdiction between Member States” in respect of criminal matters. ${ }^{26}$ In terms of exercising that competence, the EU is subject to the principles of subsidiarity and proportionality and therefore it must be shown that the objectives of the measure cannot sufficiently be achieved by the Member States acting alone and that the means of achieving such objectives are both proportionate and necessary. To this end the Commission reported in its initial impact assessment screening that 'due to the fact that situations involving both jurisdiction conflicts and the applicability of the ne bis in idem principle can affect two or more Member States, it is not possible to effectively solve them by the

\footnotetext{
${ }^{24}$ In particular the 'enforcement condition' currently enshrined within the definition of the principle in Article 54 CISA and the three grounds for exception listed in Article 55(1) CISA.

${ }^{25}$ Discussed further below. See also M.Wasmeier and N.Thwaites op. cit, supra no. 8 at 577

${ }^{26}$ The Green Paper also suggests that Article 31(1)(c) EU might serve as a complementary legal basis. The Commission Green Paper responds to point 3.3 of the Hague Programme (Presidency Conclusions, 4/5 November 2004) which calls for the effective implementation, without delay of the 2000 Commission Mutual Recognition Programme op. cit. supra note 7. In particular point 2.3 of the latter states that it is "necessary to facilitate the settlement of conflicting claims to jurisdiction between Member States and, wherever possible, to avoid multiple prosecutions.” Measure 11 of this Programme calls for an "instrument enabling criminal proceedings to be transferred to other Member States" and “criteria to help jurisdiction”, and measure 1 calls for a "reconsideration” of Articles 54-57 CISA with "a view to full application of the principle of mutual recognition."
} 
sole action of the Member States. The procedural laws of the Member States would have to be aligned so that common rules are adopted as to how they should react when faced with jurisdiction conflicts. ${ }^{27}$ In the Green Paper the Commission further justifies EU level action by reference to three objectives underpinning an EU approach to conflicts of jurisdiction and the ne bis in idem principle - all of which contribute to the further developing of the Union as a common Area of Freedom Security and Justice.

First, common EU measures could reduce the restrictions and burdens that fall on individuals in situations of multiple prosecutions. Additional burdens for the defendant include the duplicated costs of legal representation, coercive measures to the person and property, and psychological burdens associated with the extended procedures and absence of finality. The adoption of a common mechanism for deciding upon a single appropriate forum for prosecution and a clearer and more expansive interpretation of the ne bis in idem rule is likely to enhance defence rights in an EU area of justice. It is submitted that this would go some way to addressing what appears to be an unbalanced agenda of EU legislative progress in favour of the repressive elements of criminal justice.

Second, a common EU approach would reinforce and complement the cornerstone principle of mutual recognition, which asserts that a judicial decision taken in one Member State is recognised and - where necessary - enforced by other Member States $^{28}$. In its 2005 Communication on Mutual Recognition ${ }^{29}$, the Commission stated

\footnotetext{
${ }^{27}$ Commission Work Programme 2006 Roadmap 2006/JLS/010. Available at http://ec.europa.eu/governance/impact/docs/ia_2006/wp2006_roadmaps.pdf (accessed 30.9.2007)

${ }^{28}$ The promotion of a coherent criminal justice policy was identified as a priority for the Commission in its Communication of June 2004 which provided an assessment of the Tampere Programme and
} 
explicitly that 'reinforcing mutual trust is the key to making mutual recognition operate smoothly'. It anticipated that this could be achieved through legislative means (harmonising substantive and procedural law where necessary) and through practical flanking measures (such as improved evaluation mechanisms, judicial training initiatives and promoting networking among national practitioners of justice.) In respect of legislative measures, the Commission suggests that this can revolve around two axes: ensuring that mutually recognised judgements meet high standards in terms of securing personal rights and also ensuring that the courts giving the judgments really were the best placed to do so. Accordingly, mutual recognition and a sound mechanism for guaranteeing a balanced choice of jurisdiction are interdependent. Moreover, the European Court of Justice has endorsed the link between the principle of ne bis in idem and the principle of mutual recognition in its Gözutok/Brügge ruling. ${ }^{30}$ It even goes as far as to say that the ne bis in idem principle implies that Member States have mutual trust in their criminal justice systems and that each of them recognises the criminal law in force in the other Member State, even when the outcome would be different if its own national law were applied. ${ }^{31}$ The adoption of a transparent and common procedure to determine the most appropriate place for conducting a prosecution should facilitate mutual recognition in the following practical ways - if Member States are agreed upon where the prosecution is to take place it should make it easier to gather evidence at the pre-trial stage and it should

future orientations in the field of AFSJ. COM(2004) 401. It proposes that a single instrument should gradually replace the entire current system of mutual legal assistance, in particular for all questions concerning the obtaining of evidence. This "will have to be accompanied by measures to clarify the allocation of jurisdiction in order to prevent and solve conflicts of jurisdiction."

${ }^{29}$ Communication on the mutual recognition of judicial decisions in criminal matters and the strengthening of mutual trust between Member States COM(2005) 195, Brussels, 19.5.2005. See also Annexed Staff Working Paper SEC(2005) 641, Brussels, 19.5.2005.

${ }^{30}$ Joined Cases C-187/01 and C-385/01, Hüseyn Gözütok and Klaus Brügge, [2003] ECR I-1345.

${ }^{31}$ See paragraphs 32 and 33 of the judgement. 
also encourage Member States to recognise and enforce the final decision (thereby also avoiding ne bis in idem situations.)

Third and finally, EU measures in respect of multiple prosecutions should aim to increase the efficiency and swiftness of the national investigations and subsequent prosecutions which could be prosecuted by two or more Member States.

With these objectives in mind and taking account of the fact that the current raft of rules and practices on jurisdiction are 'piecemeal' and 'insufficient,' the Commission suggests that conflicts of jurisdiction in criminal proceedings ${ }^{32}$ within the Union can most appropriately be addressed by providing:

1) A common mechanism that would facilitate the choice of the most appropriate jurisdiction at the pre-trial stage thereby preventing multiple prosecutions for the same case and resolving any conflicts of jurisdiction. Such a mechanism should include an appropriate procedure and the substantive criteria to facilitate a balanced choice of jurisdiction.

\footnotetext{
${ }^{32}$ The Commission understands the term 'criminal proceeding', in its broadest sense, to include all stages of a criminal case - investigation, prosecution and trial. However its Green paper is only concerned with the question of parallel proceedings from the moment that criminal proceedings reach the prosecution phase. Also regarding the scope of the measures in the Green Paper, the Commission makes clear that is not intended to deal with the system created by Article 85 EC in order ensure the enforcement of EC competition law (Articles 81 and 82 EC), namely, Regulation No 1/2003. See SEC(2005) 1767 at 12 . The Green Paper only touches briefly upon relations with third countries in respect of the ne bis in idem principle, by simply asking the question whether a more coherent approach should be adopted, and it does not address issues concerning the international jurisdiction of the International Criminal Court.
} 
2) A revised definition of the EU wide principle of ne bis in idem, in the light of both ECJ jurisprudence and the existence of a common mechanism to facilitate choice of jurisdiction (as mentioned in the previous point.) ${ }^{33}$

\section{$\underline{\text { Green Paper: Main Proposals }}$}

\section{Preventing and Resolving Positive conflicts of jurisdiction}

The Green paper falls short of suggesting fully harmonised rules on jurisdiction (as in the field of civil law cooperation) but rather suggests that Member States be obliged to resolve positive conflicts of jurisdiction within a common procedural framework and on the basis of some suggested substantive criteria. An effective mechanism consists of two fundamental prerequisites. First, an appropriate means of information exchange so that competent national authorities can be aware of relevant proceedings and decisions in each other's jurisdiction. Second, once aware of proceedings in other Member States, the relevant authorities should have the ability to refrain from the initiation of a prosecution or halt an existing prosecution, on the mere ground that the same case is being prosecuted in another Member State. ${ }^{34}$

\footnotetext{
${ }^{33}$ Note that these two stages are broadly similar to the framework suggested by the Freiburg Proposal (framework for choice of jurisdiction and ne bis in idem rule). However, unlike the Commission's suggested approach, the Freiburg Proposal also included the 'safety-net' accounting principle as a third stage. The Freiburg Proposal, op cit, supra note 22.

${ }^{34}$ In some national legal orders this may be contrary to a duty to prosecute every crime which falls within their competence (the so-called 'principle of legality.') Arguably, this legality principle would be satisfied when another Member State prosecutes a case in accordance with the principle of mutual recognition in a common Area of Freedom, Security and Justice. However, full consideration must be given to the impact of any emergent EU rules on fundamental principles of criminal procedural law, which may be distinctive to national legal systems and constitutionally enshrined. Questions concerning the compatibility of national legislation implementing EU third pillar legislation have already arisen in the constitutional courts of several Member States. See for instance Judgement of the Bundesverfassungsgericht (German Federal Constitutional Court) of 18 July 2005 (2 BvR 2236/04), in
} 
With these prerequisites in place the Commission suggests the following three, possibly four, procedural steps.

Step 1: Identify and inform interested national authorities in relevant Member States where 'significant links' to another State can be identified by the State which has initiated or is about to initiate criminal prosecution. The informed authorities would then have a fixed period of time within which to express their interest in prosecuting the case in question. If there is no expression of interest from the informed authorities, the initiating State could continue with the prosecution without further consultations.

Step 2: Where two or more Member States have an acknowledged interest in commencing a prosecution, a second stage would involve a duty to engage in direct consultation and discussion between them in order to decide upon the "best place" to prosecute. There would be an optional possibility of asking for the assistance of Eurojust and/or 'other Union mechanism of assistance., 35 Where this step leads to an early consensus on the best place for prosecution, the national authorities will accordingly either close, halt or refrain from

which it declared that the national legislation implementing the European Arrest Warrant Framework Decision was incompatible with the German Constitution. Moreover, the Belgian Constitutional Court referred a question to the ECJ which inter alia asks whether certain provisions of the Framework Decision on the European Arrest Warrant are compatible with Article 6(2) EU and more specifically with the principles of legality in criminal proceedings and the principle of equality and nondiscrimination. The ECJ confirmed their compatibility. See Case C-303/05 Advocaten voor de Wereld VZW v Leden van de Minsterraad Judgement of 3 May 2007 (nyr).

${ }^{35} \mathrm{~A}$ co-ordinating forum similar to that used in the field of EC competition law (the European Competition Network) might be considered in order to facilitate closer ties and mutual trust between the prosecution authorities of the Member States. 
initiating proceedings ${ }^{36}$ or initiate/continue with proceedings according to their national law. The Commission suggests that national authorities may, in certain circumstances, wish to enter into binding agreements to ensure legal certainty and to avoid, or at least regulate, the risk of reopening the debate on where to prosecute. In such circumstances it suggests the possibility of relying upon an EU Model Agreement, which could, inter alia, provide some common rules for the denunciation of such agreements and the circumstances which would allow for the reopening of the consultation procedure.

Step 3: Dispute resolution/mediation would be needed where agreement cannot easily be found or when no agreement has been reached after a certain amount of time. This step aims to assist Member States in the resolution of real jurisdiction conflicts through a framework of structured dialogue involving a body at EU level acting as a mediator. This dispute resolution mechanism must be swift and flexible and could be initiated upon the request of any interested Member State or it could begin automatically after an elapsed period of time. Eurojust would be the obvious candidate to take on this role and indeed it has formally expressed its desire to have a dispute resolution function conflict of jurisdiction, European Arrest Warrant and mutual legal assistance cases. ${ }^{37}$ The Green Paper however also raises the possibility of creating an entirely new body (for example a panel composed of senior national prosecutors or judges) to take on this role.

\footnotetext{
${ }^{36}$ The annex to the Green Paper adds that the closing of proceedings/non-initiation of proceedings in one State should not be a bar to the provision of mutual assistance to the leading jurisdiction. This would reflect the ECJ's ruling in Case C-469/03 Filomeno Mario Miraglia [2005] ECR I-2009.

${ }^{37}$ Eurojust's contribution for the European Commission Communication concerning the future of Eurojust and the European Judicial Network. Council Document 13079/07. Brussels, 20 September $2007,1-21$ at 8
} 
The Commission suggests that steps 1-3 could be established in the short term and may be considered sufficient unless further experience would reveal a need for further steps.

(possible additional) Step 4: The Commission raises the longer term possibility of considering whether an EU level body should be empowered to take a binding decision as to the most appropriate jurisdiction in the event that the suggested dispute settlement in steps 1-3 fails. It states that this step would require the setting up of an entirely new body because Eurojust cannot act as both mediator and decision-maker. It also raises the need for recourse to judicial review at the EU level of any binding EU level decision. Currently, the ECJ has no competence to provide such a role.

In addition to the suggested procedural mechanism above, the Commission proposes that a complete strategy to prevent and resolve conflicts of jurisdiction should also include a priority rule - which would oblige Member States to concentrate prosecution proceedings in a "leading” Member State, ${ }^{38}$ and a list of relevant criteria to be used by Member States in choosing the leading jurisdiction. The Commission suggests that it is feasible to define a number of relevant objective criteria, which are to be applied and weighed up on a rather flexible and case-by-case basis. It offers the following non-exhaustive list of possibilities - territoriality, criteria related to the suspect or defendant, victims’ interests, criteria related to State interest, and certain

\footnotetext{
${ }^{38}$ This rule would apply from the moment of the sending of an accusation/indictment before a national court -at that stage that the necessary information needed for a thorough assessment of jurisdiction issue will be available to the competent authorities - prior to that it might be too early to make a definitive choice of jurisdiction since new findings can change the picture of what at first might seem the best place to prosecute.
} 
other criteria related to efficiency and rapidity of the proceedings. A negative list might also be considered - ie those factors which should not be of relevance in deciding the issue of jurisdiction, such as resources and costs of prosecuting. Furthermore it is suggested that Member States might agree on some basic principles on the prioritisation or sequencing within the list of criteria to be included in an EU instrument. It is suggested that territoriality might reasonably be prioritised on any list of criteria. If a more flexible approach is preferred (that is, no priority of criteria) it might at least be appropriate to agree on some broad guiding principles for jurisdiction allocation, such as reasonableness or due process.

Finally, on the matter of conflicts of criminal jurisdiction, the Commission raises the issue of involving the individual suspect in the determination of the most appropriate jurisdiction and the need to ensure effective remedies for the individual in the form of judicial review. The Green Paper notes that the envisaged consultation/discussion phase is to be conducted between competent authorities rather than with the individuals concerned. It considers that the risk to victims and witnesses arising from the revelation of facts in a discussion of jurisdiction issues with defendants is a matter which "could probably be left to be decided by the national courts". The Green Paper acknowledges that the defendant would have to be informed of the main reasons for a choice of jurisdiction at the latest at the time an indictment is presented to a court. In the event of a non-binding consensual jurisdiction allocation, the question of whether to provide judicial review could be left to the discretion of Member States, in accordance with national law. However, where a case is allocated to a specific jurisdiction through a binding EU Model Agreement it would seem necessary to provide for a judicial review of any emergent decision at the request of the individuals 
concerned. This is because such binding agreements would fetter the ability of the

Member State concerned to denounce the jurisdiction allocation at a later stage. In the event that an EU body is given the power to determine allocation of jurisdiction (additional step 4 above), judicial review at the EU level would be indispensable but that is currently legally impossible. ${ }^{39}$ Under the current EU Treaty framework only national courts are competent to perform judicial review of specific jurisdiction allocations. $^{40}$

The Principle of Ne bis in Idem

The Green Paper constitutes a welcome opportunity to reconsider the ne bis in idem principle as enshrined in Articles 54 to 58 of the CISA alongside the issue of conflicts of jurisdiction. With the establishment of a balanced mechanism for choice of jurisdiction it was thought that discussion on ne bis in principle principle could be "re-launched with increased prospects of success." No longer would it act, as it currently does, as a limited and arbitrary mechanism for the allocation of jurisdiction. Three issues relating to ne bis in idem are identified as requiring further consideration;

First - whether there is a need to clarify certain elements and definitions of the principle, for instance what types of decisions can have an ne bis in idem effect,

\footnotetext{
${ }^{39}$ Note that Article III-359 of the Constitutional Treaty would have conferred sufficient competence on the ECJ in this regard.

${ }^{40}$ Also note that he jurisdiction of the ECJ pursuant to the third pillar is currently limited in terms of scope and by its non-mandatory status. See Article 35 EU. The Green Paper mentions that any questions on the interpretation of future EU rules on deciding upon the appropriate criminal jurisdiction could be referred to the ECJ for preliminary rulings. However, for those Member States that have not accepted the jurisdiction of the ECJ (UK, Denmark and Ireland) such questions cannot be referred. The view that the role of the ECJ as regards `should be aligned with the general scheme of jurisdiction in the Community pillar has been long since advocated in scholarly work and by the Commission and European Parliament. It looks likely that the text of the Reform Treaty will follow the lead of the now defunct Constitutional Treaty and extend the ECJ's jurisdiction in this way.
} 
and what is to be understood by term “idem”. Certainly, any forthcoming piece of legislation on this issue must take account of the ever-expanding ECJ jurisprudence on the interpretation of the ne bis in idem principle as contained in Articles 54-58 CISA. It would appear that the suggested definition as regards the scope of ne bis in idem in the Green Paper of "a decision in criminal matters which has either been taken by a judicial authority or which has been subject to an appeal to such an authority” does not adequately reflect the ECJ's jurisprudence.

Second - in case of a conviction, the principle currently applies only where the imposed penalty "has been enforced, is actually in the process of being enforced or can no longer be enforced..." Could this enforcement condition be removed? ${ }^{41}$ Certainly, its abolition would appear less problematic were effective mechanisms for determining the competent jurisdiction to exist. Moreover, the enforcement condition is arguably superfluous within an area of EU criminal justice, where cross border enforcement is facilitated by EU instruments (such as the European Arrest Warrant Framework Decision) based upon the principle of mutual recognition. However, certain Member State Governments have expressed their reluctance to remove the enforcement condition in the absence of further compelling evidence. The ECJ has now ruled on the notion of 'enforcement' of criminal penalties $^{42}$ within the meaning of Article 54 CISA and a further request for a preliminary ruling is pending. ${ }^{43}$

\footnotetext{
${ }^{41}$ The purpose of the enforcement condition is to avoid impunity for absconding convicts in cases where a conviction is not (fully) enforced, the rationale being that the protection against a second proceeding is only justified if the original sentence has been enforced.

${ }^{42}$ Case C-288/05 Kretzinger.

${ }^{43}$ Case C-297/07 Klaus Bourquain.
} 
Third - it is questioned whether the current possibilities for derogation from the principle are still necessary with the creation of a balanced and effective mechanism for determining jurisdiction. Where national interests are taken into account at the earlier pre-trial stage of deciding upon an appropriate jurisdiction for prosecution and in a system of judicial cooperation based upon mutual recognition, it no longer seems appropriate to allow Member States to unilaterally assert exceptions to the principle of ne bis in idem based upon purely national self interest, such as national security offences or acts of state officials. It is submitted that exceptions to the right enshrined in the ne bis in idem rule should be limited to procedural irregularities/abusive conduct in respect of the first proceedings and the emergence of decisive, new evidence.

Whatever the range of views on each of these three issues, any forthcoming legislation revising the principle of ne bis in idem must take full account of the raft of relevant ECJ caselaw to date. Interestingly, the large majority of cases delivered or pending before the ECJ in respect of the third pillar of the EU have been references from national courts concerning precisely the interpretation of the ne bis in idem rule as contained in CISA. ${ }^{44}$ A general analysis of the caselaw delivered to date would be to say that the ECJ's approach is one of adopting a broad interpretation of its scope and a narrow interpretation of its exceptions. ${ }^{45}$ Its caselaw has been most instructive in clarifying the meaning of the ne bis in idem principle laid down in CISA and importantly it has also revealed how the ECJ conceives of the AFSJ more generally.

\footnotetext{
${ }^{44}$ Article 54 of the CISA reads that '[a] person whose trial has been finally disposed of in one Contracting Party may not be prosecuted in another Contracting Party for the same acts provided that, if a penalty has been imposed, it has been enforced, is actually in the process of being enforced or can no longer be enforced under the laws of the sentencing Contracting Party.' For 'Contracting Party' read Member State.

${ }^{45}$ This is reminiscent of the Court's approach to the 'four freedoms.'
} 
To its credit, the ECJ offers a consistent and broad, (although not unlimited,)

interpretation and the impact of the caselaw is to strengthen the practical application

of the principle as a transnational fundamental right offering increased levels of

protection for individuals. In reaching its judgements the ECJ has been strongly

influenced by the operation of the principle within the broader integration objective of maintaining and developing the EU as an Area of Freedom, Security and Justice in

which the free movement of persons is guaranteed and protected. In particular it views the objectives of the ne bis in idem principle as inextricably linked to achieving the right to free movement; it consistently states that the objective of the principle is to ensure that "no-one is prosecuted on the same facts in several Member States on account of his having exercised his right to freedom of movement." ${ }^{\text {46 }}$ It endorses the principle as necessarily and implicitly imposing mutual recognition of final decisions in criminal proceedings, thereby also endorsing the political decision to place mutual recognition at the heart of judicial cooperation in criminal matters. There is, according to the ECJ “a necessary implication that the Member States have mutual trust in their criminal justice systems and that each of them recognises the criminal law in force in the other Member States even when the outcome would be different if its own national law were applied." ${ }^{47}$ As such, diverse national rules on for example, time

\footnotetext{
${ }^{46}$ First laid down in Joined Cases C-187/01 and C-385/01 Gözütok at para.38 and elaborated further in Case C-436/04 Van Esbroeck.

${ }^{47} \mathrm{C}-385 / 01$ Gözütok at para. 33. In sum, the provisions of CISA are to be interpreted on the basis of an assumption that Member States have mutual trust and confidence in each other's legal systems. A blanket assumption of mutual trust is arguably problematic, at least in practice. For a critique see A.Weyembergh, 'Approximation of Criminal Laws, the Constitutional Treaty and the Hague Programme' (2005) CMLRev 42 1567-1597 at 1575; S. Peers, 'Mutual Recognition and Criminal Law in the European Union: Has the Council Got it Wrong?' (2004) CMLRev 41 5-36. Rather, mutual trust must be built and secured through positive measures and cannot be simply implied or assumed. In other words the conditions for the smooth and effective application of mutual recognition must be created. The AFSJ strategy, as developed by the Council and the Commission now appears to acknowledge the need to 'build' trust through a variety of different approaches, including the adoption of harmonising legislation in respect of criminal procedures and practical, non-legislative measures such as judicial training and personnel exchange schemes. See Communication on the mutual recognition of judicial decisions in criminal matters and the strengthening of mutual trust between Member States $\operatorname{COM}(2005)$ 195. For an analysis of the role of mutual trust and the means of achieving it in the context
} 
bars to prosecution ${ }^{48}$ could be embraced by the ne bis in idem principle because its

application is not made conditional upon any requirement for harmonisation. By

promoting the free movement imperative and endorsing the mutual recognition

principle the ECJ is able to put forward expansive interpretations of concepts such as

"bis" ${ }^{49}$ and "idem"50 because to do otherwise would be to undermine the principle or

its (essentially) free movement objective. ${ }^{51}$ However it would be wrong to suggest

that the Court determines the appropriate scope of the 54 CISA principle solely by

reference to the 'free movement justification'. ${ }^{52}$ Rather, a closer analysis of some of

the caselaw ${ }^{53}$ reveals that other factors pertinent to the conception of the AFSJ as a

of the third pillar see G.de Kerchove and A.Weyembergh (eds) La Confiance Mutuelle au sein de l'Espace pénal Européen. Mutual Trust in the European Criminal Area (Éditions de L’Université de Bruxelles, 2005)

${ }^{48}$ Case C-467/04 Gasparini

${ }^{49}$ See C-385/01 Gözütok in which the Court held that an out-of-court financial settlement by a public prosecutor which discontinued criminal proceedings and barred a further prosecution according to national law, could have ne bis in idem effect in another Member State. In C-467/04 Gasparini, the Court held that the principle also applied to a decision of a court by which the accused was acquitted finally because prosecution of the offence was time-barred, and in Case C-150/05 Van Straaten, the Court held that not to apply the principle to a final decision acquitting the accused for lack of evidence would have the effect of jeopardising the exercise of the right to free movement and undermining the principles of legal certainty and the protection of legitimate expectations. However, the Court in Case C-469/03 Filomeno Mario Miraglia confirmed that not all decisions barring further prosecution according to the law of the Member State in which it is given should produce a ne bis in idem effect in other Member State. In effect, the CISA principle had been used on the facts of this case to prevent effective criminal proceedings being brought against Mr Miraglia anywhere. In these circumstances the decision which discontinued national proceedings prior to any adjudication on the merits of the case, on the sole ground that proceedings had earlier been initiated in another Member State against the same defendant and for the same acts 'cannot constitute a decision finally disposing of the case against that person.' It would in effect, be contrary to the public interest to interpret the provisions in such a way that the alleged criminal conduct might never be considered. It would be wrong to read into this judgement a general rule to the effect that the Article 54 CISA principle only applies to decisions following an assessment on the merits of the case. In fact, in its judgement in the later case of C467/04 Gasparini the ECJ clearly rejected such a position.

${ }^{50}$ Case C-436/04 Van Esbroeck in which the Court defined "same acts" as "the existence of a set of concrete circumstances - or material acts - which are inextricably linked together in time, in space and by their subject matter, irrespective of the legal classification given to them or the legal interest protected.” Applying that definition to the facts, the Court said that the import and export of the same drugs constituted the "same acts" within the meaning of Article 54 CISA in principle, but acknowledged that this was for the national court to determine in practice. This definition has been confirmed in later caselaw. See Case C-150/05 Van Straaten, Case C-467/04 Gasparini, and Case C288/05 Kretzinger.

51 This is the familiar 'effet utile' approach of reasoning often used by ECJ. In its jurisprudence on the CISA it uses the term "proper effect."

${ }^{52}$ For an elaboration on why this would be difficult to sustain from a material and conceptual point of view, see R.Lööf op cit. supra no. ????

${ }^{53}$ Case C-469/03 Filomeno Mario Miraglia and Case C-150/05 Van Straaten 
whole must also be weighed in the balance, such as the objective of "preventing and combating crime” ${ }^{54}$ and the fact that the ne bis in idem principle constitutes a general principle of EU law, and as such incorporates other principles, such as the legal certainty and legitimate expectations. ${ }^{55}$

Undoubtedly, a variety of intricate legal problems can stem from different interpretations of the ne bis in idem principle by different jurisdictions. For example, problems may arise from the practice unique to civil law jurisdictions which allows for an appeal by the prosecutor against acquittal as part of 'one trial.' The precise meaning and scope of the principle may therefore only emerge in time when tested on a case-by-case basis. That is not to say that EU legislator cannot attempt to define the principle in any forthcoming legislation, but that it must tread carefully when attempting to do so. A clear and concise definition that reflects the settled points of the recent ECJ caselaw (for instance the criteria established by the Court in Van Esbroeck for establishing the concept of the "same acts" ${ }^{\text {"56 }}$ ) without attempting to be exhaustive or prescriptive would appear to be the most appropriate course of action. A consolidation of the jurisprudence would be a useful exercise in itself and would be in the interests of both transparency and legal certainty.

\section{Main impacts of the proposals contained in the Green Paper}

\section{Individual}

A new framework for choice of forum for prosecution and a revised ne bis in idem principle will have a clear and obvious impact upon the fundamental rights of

\footnotetext{
${ }^{54}$ Article 2 EU. See C-469/03 Filomeno Mario Miraglia.

${ }^{55}$ See Case C-150/05 Van Straaten, judgement of 28 September 2006 (nyr) at para. 59.

${ }^{56}$ Case C-436/04 Van Esbroeck.
} 
individuals, particularly the suspect or defendant. It is crucial to the legitimacy of any EU approach that fundamental safeguards for the individual are built into the procedural framework for deciding upon the appropriate jurisdiction. These include for instance the imposition of strict time limits for actions to ensure timely and fair administration of justice and ensuring that the interests and position of the suspect are adequately taken account of in determining the best place for prosecution.

\section{National systems}

Any measure that seeks to find an EU level response to the problem of multiple prosecutions is bound to affect national prosecutorial systems to some degree. This is because national jurisdictions retain the fundamental right to prosecute according to their own defined rules. Common EU rules on multiple prosecutions will inevitably impact upon a Member State’s freedom to act and might even challenge constitutionally enshrined principles such as the principle of legality. EU provisions will create duties that are likely to impact upon the day-to-day operations of prosecutorial systems. For instance, new duties to consult and inform other national authorities in order to trigger the coordination mechanism may be time-consuming, complex and even impede effective combating of crime. The degree to which national systems will have to be amended will of course also depend upon which of the EU options are chosen. Steps 1-3 largely respect and indeed strengthen national claims for jurisdiction, albeit on the basis of common criteria. National criminal justice systems, with some exceptions, retain their autonomous powers. Step 4 however, ultimately removes the final decision on jurisdiction from the national level and shifts 
it to the EU level. ${ }^{57}$ As regards the principle of ne bis in idem, proposals arising from the Green Paper would undoubtedly affect the substance of the rule as it is applied in many Member States. Broad distinctions between common law and civil systems, such as the common law opposition to the civil tradition of prosecution appeals of an acquittal, result in different applications of the ne bis in idem principle. These should be considered in detail by the EU legislator.

\section{$E U$}

Impacts at the EU level will be direct and indirect. Directly, the emergence of a legislative instrument along the lines suggested in the Green Paper will entail possible amendments to existing pieces of legislation. For instance, the suggested measures on conflicts of jurisdiction could enable the EU to reduce the number of grounds for nonexecution of judicial decisions from other Member States which are currently found in EU mutual recognition instruments. ${ }^{58}$ Furthermore, it seems logical that a common $n e$ bis in idem principle should act as a mandatory ground for refusal of any judicial request be it for mutual recognition or execution of a decision, or for legal assistance. Certain mutual recognition instruments will have to be amended in order to come into line with such an approach. ${ }^{59}$ More indirectly, an EU mechanism for dealing with positive conflicts of jurisdiction and a consolidated version of the ne bis in idem principle is likely to facilitate the mutual recognition principle as discussed above.

\footnotetext{
${ }^{57}$ It should be pointed out that there is no prospect of removing the task of prosecution of crime from individual national prosecution systems. The EU debate is strictly limited to assisting the appropriate choice of jurisdiction for prosecution.

${ }^{58}$ An example might be those grounds based on the fact that an act took place in the territory of the executing state as in Article 4(7)(a) of the Framework Decision on the European Arrest Warrant.

${ }^{59}$ For instance the Framework Decision on the execution in the EU of orders freezing property or evidence only names the principle of ne bis in idem as an optional ground for non-execution. OJ [2003] L196/45. More detailed work on the legal impacts of the application of the ne bis in idem principle in the context of judicial cooperation instruments would appear necessary.
} 


\section{$\underline{\text { Comment }}$}

The current debate on jurisdiction raises the same challenges as pervade any attempt by the EU to take measures in the sphere of criminal law - namely, within the limits of legal competence and with the unanimous support of all the Member States, how to ensure the effective enforcement of criminal law while securing the procedural rights of individuals within the judicial process. It is suggested that in seeking to achieve this balance that the debate on criminal jurisdiction is situated in the context of several broader debates that resonate the field of EU criminal law cooperation.

Human rights protection in criminal matters in the $\mathrm{EU}$

The commitment to respecting human rights in the development of an Area of Freedom, Security and Justice is clear from both the EU Treaty and from the various political roadmap documents that have been so influential in this field. In the context of the third pillar, the cornerstone principle of mutual recognition of judicial decisions presupposes that Member States have trust in each other's criminal justice systems. That trust is said to be grounded, in particular, on their shared commitment to the principles of freedom, democracy and respect for human rights and fundamental freedoms and the rule of law. It is for national legal systems to uphold relevant human rights protections as enshrined inter alia in the European Convention on Human Rights. However, concerns have been expressed as to the adequacy of relying upon national law systems to uphold human rights protection in an increasingly borderless system for criminals, criminal prosecutions and criminal judgments advocated by EU 
law. ${ }^{60}$ And while the need for certain common procedural safeguards for criminal suspects has been acknowledged by EU leaders as a necessary complement to increasing cross-border (and repressive) efficiency through the mutual recognition of criminal judgments, efforts to produce a legislative text have been ultimately fruitless. ${ }^{61}$ Securing 'added value’ to existing ECHR protections has not been possible. This is perhaps worrying, not only from the perspective of the individual suspect whose rights remain inadequately safeguarded at the EU level but also from a broader perspective concerning the nature (and ultimately legitimacy) of the emerging European 'area of justice. ${ }^{62}$ There is no doubt that the current debate on multiple prosecutions and the forthcoming legislative proposal could have a major impact from both of these perspectives and must take account of the EU's current and prospective commitment to upholding human rights. ${ }^{63}$

\section{An evolving European Judicial Space}

The second debate of relevance for the issues discussed in the Green paper is one that ultimately hinges upon ones perception of a ‘European judicial space.’ To what extent should the EU move beyond powers of cooperation and coordination in the field of criminal matters to attaining enforceable powers of direct intervention? That question

\footnotetext{
${ }^{60}$ See for example E.Guild, 'Crime and the EU's Constitutional Future in the Area of Freedom, Security and Justice', (2004) 29(2) European Law Review 219-242 and S.Alegre and M.Leaf, 'Mutual Recognition in European Judicial Cooperation: A Step Too Far Too Soon? Case Study - the European Arrest Warrant', (2004) 10(2) European Law Journal 200-217.

${ }^{61}$ Proposal for a Council Framework Decision on certain procedural rights in criminal proceedings throughout the European Union (COM (2004) 328 final.) On the legal constraints and the substantive failings of this legislative proposal see R. Lööf, 'Shooting from the Hip: Proposed Minimum Rights in Criminal Proceedings throughout the EU’ (2006) 12(3) European Law Journal 421-430.

${ }^{62}$ While human rights are not an explicit bar to mutual recognition in European legal instruments, Member State implementation of and reliance upon derogations from EU law must be compatible with general principles of EC/EU law which includes the protection of fundamental rights.

${ }^{63}$ A further strengthening of human rights protection in the EU Area of Freedom, Security and Justice had been anticipated by the EU Constitutional Treaty which if ratified would have incorporated the EU Charter into the EU Treaty framework transforming it into a legally binding document, while accession of the EU to the European Convention on Human Rights would have become a legal possibility.
} 
is of course distinct from the question of whether the EU is legally able to act in such a way. This latter question is presently answered in the negative with reference to the principle of conferred competences in EU law. To date, responses to the initial question have been met with scepticism. Proposals to introduce a European Public Prosecutor to ensure the effective combating of financial crime committed against the European Community were first suggested in 1997 in the Corpus Juris project. ${ }^{64}$ At the time, this proposal was quite revolutionary - conferring autonomous powers of investigation and prosecution upon a European body - and was deemed in many quarters as being both undesirable and unnecessary. However, almost a decade on, and with a raft of legislative instruments in place (or forthcoming) to secure immediate recognition and enforcement of national criminal judgements and, in some areas of serious cross border-crime, common definitions of offences and penalties, at least the prospect of a European 'body' with direct powers to decide upon whether or not to prosecute certain 'euro-crimes' (in a national court) is more conceivable. In this regard, the Constitutional Treaty contained a provision enabling the establishment of a European Public Prosecutors office 'from Eurojust. ${ }^{, 65}$ Although its establishment would still require a unanimous approval from Member State governments, the very inclusion of this provision in the text of the Constitutional Treaty is remarkable. As things stand however, and with no possibility of the Constitutional Treaty entering into force, there is no European Public Prosecutor. The debate however lingers on. A less 'intrusive’ approach has been mooted - that of conferring powers on Eurojust to take a binding decision in respect of where to prosecute an offence. Indeed a similar option was raised in the Green Paper at step 4. Again, however, this would require the

\footnotetext{
${ }^{64}$ Corpus Juris, introducing provisions for the purpose of the financial interests of the European Union, under the direction of Mireille Delmas-Marty, Economica, Paris, 1997. See also M.Delmas-Marty et al. (eds) The implementation of the Corpus Juris in the Member States, vol 1-4, 2000-2001.

${ }^{65}$ Article III-274 Treaty establishing a Constitution for Europe.
} 
conferral of additional legal competence upon the EU and securing the requisite political will would appear to be problematic. Although some Member States support such a role for Eurojust, the UK House of Lords ${ }^{66}$ has expressed its clear opposition saying that it was premature and that it would transform Eurojust into a 'quasiprosecutorial authority' and bring it very close to the European Public Prosecutor. In such a climate of vociferous political opposition, it is hardly surprising that the Commission presents the step 4 option of EU binding powers, as being complex and for the future.

A less intrusive approach still is offered by the Commission in the form of a procedural framework to enable allocation of jurisdiction (steps 1-3 above). The suggested framework for consultation/discussion and dispute settlement would be binding upon national authorities but any decision as to where to prosecute would be taken by the national authorities themselves and would not constitute a 'EU decision.' This option is, in principle, likely to be more acceptable to the Member States, although as we have seen, the devil lies in the detail. Key issues remain, including how to ensure any future EU mechanism for case allocation does not lead to inordinate delays in the prosecution process which would impact detrimentally upon the trial of the accused. The scope of application of any future EU mechanism is also likely to be a key issue for the Member States. Should the mechanism be used in respect of all cases involving positive conflicts of criminal jurisdiction between the Member States (or only for those involving crimes that have been harmonised by EU law or those for which dual criminality has been abolished, as listed in the annex to the Framework Decision on the European Arrest Warrant?)

\footnotetext{
${ }^{66}$ Report of House of Lords EU Committee, 'Judicial Cooperation in the EU: the role of Eurojust', HL Paper 138, $23^{\text {rd }}$ Report of Session 2003-04.
} 
These and other issues raised by the Green Paper cannot be divorced from a wider consideration of the nature and purpose of a 'common area of justice' and how best to achieve commonly agreed objectives within that area. For instance if one considers the key consideration to be the effective protection of the individual suspect within an EU criminal area, then it arguable that the cooperation mechanism in steps 1-3 of the Green Paper, fails to offer sufficient guarantees in this regard. It facilitates case allocation but does not guarantee it, and any judicial redress for the individual in terms of ability to question an allocation decision is determined by national law which is likely to vary. Arguably only a binding EU decision on case allocation by a EU judicial body (such as the European Court of Justice or a new preliminary chamber thereof) would fully circumvent the risk of a breach of the ne bis in idem principle and also avoiding problems of divergence and inconsistency that might arise where this role is carried out by national judicial bodies. Alternatively, of course, where the major consideration is one of improving the efficiency of prosecutions within Member States and law enforcement more generally, then a different solution emerges - one which strictly limits the input of the EU to facilitating co-operation between national agencies.

\section{Pre-legislative scrutiny}

Finally, in a policy field as contentious as European criminal law it is vital that prelegislative debate and scrutiny is robust. The Commission has committed itself to identifying, at the pre-proposal stage, the 'added value' at the European level of any legislative and non -legislative initiatives to be taken in the area of Freedom, Security 
and Justice. ${ }^{67}$ In so doing it has acknowledged that the so-called Better Regulation Strategy, traditionally associated with improving decision-making in the first pillar (and also associated with meeting the Lisbon Agenda objectives), also applies to the third pillar. Better Regulation mechanisms such as extended impact assessments will therefore be carried out on the main proposals to be presented. Impact assessments seek to ensure that policy is made in full knowledge of the facts and awareness of the implications. Investing time and effort at the pre-proposal stage is of particular importance in respect of third pillar issues for at least two reasons. First, the sensitivity of the subject matter for Member States, in a sense, raises the bar in terms of satisfying the principle of subsidiarity and identifying added value. Wide-ranging consultation combined with specific supporting empirical research is required to achieve the dual aim of securing the requisite unanimous support from Member State governments and achieving something more than simply a lowest common denominator output. Second, pre-legislative efforts to improve the content of a particular measures takes on an added significance in a legal environment that lacks a post-legislative enforcement mechanism to bring recalcitrant Member States before the ECJ. The experience of the European Arrest Warrant Framework Decision reveals clearly that unanimous political endorsement of a proposal is no guarantee of effective implementation and application at the national level. ${ }^{68}$ The public consultation initiated by the Commission’s Green paper on criminal jurisdiction

\footnotetext{
${ }^{67}$ See Commission Communication - The Hague Programme: Ten Priorities for the next five years. The Partnership for European renewal in the field of Freedom, Security and Justice COM (2005) 184, also known as ‘the Hague Action Plan’ at point 2.3.

${ }^{68}$ See Commission Evaluation Reports COM(2006)8 final. Brussels, 24.1.2006 and COM(2007)407 final. Brussels 11.7.2007. Also see also Case C-303/05 Advocaten voor de Wereld VZW v Leden van de Minsterraad judgement of 3 May 2007 (nyr) in which the Court upheld the compatibility of the EAW Framework Decision with the EU Treaty on both procedural and substantive grounds. This challenge to the EAW framework Decision came from the Belgian Cour d'Arbitrage. For more information on the case see Council Document No. 11518/05 of 4.8.2005
} 
marks only the latest stage in the process of impact assessment. ${ }^{69}$ As a result of the reactions to the Green Paper the Commission has committed itself to assessing what further consultations and work is required. Already it is clear from some responses to the Green Paper that a stronger evidence base is required in order to properly justify and ensure an appropriate EU approach, reflecting what appears to be an almost generic failing in recent Commission third pillar proposals. The Standing Committee of experts on international immigration, refugees and criminal law ${ }^{70}$ commented in their response that 'The Commission presumes that conflicts of jurisdiction are a serious problem in the efficiency of efforts to combat crime. That may be so. However, this claim is not substantiated. No statistics have been produced to demonstrate the character and remit of the problem caused by the theoretical existence of positive conflicts of jurisdiction.' The European Criminal Bar Association (ECBA) also comments that the Green Paper provides no empirical data on which the proposal has been based and calls for a more thorough examination of the conflicts of jurisdiction and the principle of ne bis in idem in an enlarged EU. ${ }^{71}$ It seems therefore that the Commission has more work to do to demonstrate that a formal mechanism for allocating jurisdiction has significant added value over the existing voluntary mechanisms that exist to date and, moreover, that the full implications of such a formal mechanism, particularly in respect of the defendant, are taken into account. In this context the consultation period envisaged in the Green Paper $^{72}$ was too short and

\footnotetext{
${ }^{69}$ An overview of the impact assessment plans in respect of this measure is provided in the Roadmap 2006/JLS/010.

${ }^{70}$ http://www.statewatch.org/news/2006/apr/meijers-committee-reaction-ne-bis-in-idemGreenpaper.pdf (accessed on 30.10.2007)

${ }^{71}$ http://www.ecba.org/extdocserv/jurisdictionnebisinidemresponsefinal.PDF (accessed on 30.10.2007)

${ }^{72}$ Which ran from the date on which the Green Paper became publicly available (which was some time after its adoption on 23.12.2005), until 31.03.2006.
} 
the deadline of the end of 2006 for the publication of a draft framework decision ${ }^{73}$ was too ambitious.

\section{Conclusion}

The on-going discussions relating to the introduction of an EU legislative instrument to tackle the problem of multiple prosecutions are to be broadly welcomed. Existing legal provisions at both the international and EU level do not currently provide a sufficiently clear and robust solution to jurisdiction conflicts, which in turn distorts and limits the ne bis in idem principle. The ECJ has laid the foundation for the transnational application of the ne bis in idem principle as a human right, but this approach to achieving equivalent protection in the EU is necessarily limited by the 'chance' of litigation. The EU legislator now has the opportunity to build upon the ECJ's lead in respect of this principle but also to consider it in the wider context of conflicts of jurisdiction in a developing Area of Freedom, Security and Justice. However it has its work cut out. While few would disagree with the fundamental objective of securing one prosecution for one offence, devising an appropriate procedure for achieving this is likely to be more difficult, not least baring in mind the diverse systems of criminal law and procedure across the European Union. To this end it may therefore be helpful and necessary to engage in further reflection upon the 'principles behind the principle. ${ }^{74}$ Traditionally, the principle of ne bis in idem has been founded upon the dual bases of securing due process rights for the individual and securing finality of judgments in order to legitimise the legal order. The EU's Area of

\footnotetext{
${ }^{73}$ See Commission Communication - The Hague Programme: Ten Priorities for the next five years. The Partnership for European renewal in the field of Freedom, Security and Justice COM(2005) 184, also known as ‘the Hague Action Plan’ at point 4.1.
} 
Freedom, Security and Justice in which criminal law cooperation is fundamentally based upon a principle of mutual recognition offers a unique context in which to scrutinise these justifications further. Is the principle of ne bis in idem, in this context, a right to be claimed by the individual or rather a means of limiting State action? Does this depend on the whether the principle is tied conceptually to the allocation of jurisdiction or whether it is used as a means of barring judicial cooperation? Answers to these and other questions may help to reveal an effective EU approach and assist in resolving the delicate balances between mutual recognition and approximation (of both procedural and substantive law) and between assuming and promoting mutual trust. The Green Paper presents a variety of options for an EU approach which in turn, requires close and detailed scrutiny and, in some cases, further elaboration or justification. If, the protection and enhancement of individual rights of defence should remain at the forefront of the minds of the legislators throughout this debate, it may be that the mechanism of interstate consultation procedures to identify the appropriate place for jurisdiction is unable to secure appropriate guarantees in this regard and that the choice of jurisdiction should ultimately fall to a body at the EU level. Legal competence limits certainly lie in the path of this development but that should not prevent, in the context of ongoing pre-legislative consultations and discussions, a debate on its merits. A limited conferral of powers to the EU level to decide upon a choice of jurisdiction for prosecution of certain crimes in the event of multiple claims, based upon clear, objective and commonly agreed criteria and as a last resort, would conceivably strengthen the principle of mutual recognition and ensure effective and equivalent protections for the individual suspect. When viewed from this perspective, the conceptual shift from cooperation between autonomous systems of criminal justice as advocated by the national governments of the EU States 
to date, to a more integrated and vertical approach, in which the EU has some power to take binding decisions, may not be so great.

First accepted for publication December 2006

Revisions made September 2007 